\title{
Prevalence and risk profile of cervical human papillomavirus infection in Zhejiang Province, southeast China: a population-based study
}

\author{
Jing Ye ${ }^{1}$, Xiaodong Cheng ${ }^{2}$, Xiaojing Chen ${ }^{1}$, Feng Ye ${ }^{1}$, Weiguo Lü ${ }^{2}$, Xing Xie ${ }^{2^{*}}$
}

\begin{abstract}
Background: Benign or malignant lesions caused by Human papillomavirus (HPV) produce considerable health burden worldwide. Since limited cross-protection would be offered between HPV types, heterogeneity in HPV type-specific distribution should be taken into account when predicting the effect of current prophylactic vaccines and forming the basic for the second-generation vaccines targeted to specific regions. Here, we investigated the prevalence of cervical HPV infection, as well as predictors concerned, in Zhejiang Province, southeast China.

Results: Totally 4987 cervical samples from five randomly chosen counties in Zhejiang Province were detected. The overall HPV prevalence was 13.3\%. Established high-risk (HR) HPV prevalence was 10.2\%. HPV-52 was the most prevalent type (3.1\%), followed by HPV-16 (2.5\%), $-58(2.1 \%),-68(1.0 \%)$ and $-81(0.9 \%)$. HPV-16 or -18 were present in $3.1 \%$ of the detected samples, while 174 specimens (3.5\%) were positive for any of HPV-6, $-11,-16$ and -18 . The prevalence of HPV vaccine types was consistently low across age groups. Bimodal age distribution in HR-HPV, including established HR and probably HR-HPV, was observed, with a clear second peak in perimenopausal women. Multivariate unconditional logistic regression models revealed that partner's lifetime number of partners was the only common independent predictor of overall, established HR, established low-risk, single-type and multiple-type HPV infection in current study.

Conclusions: We have observed low prevalence of HPV vaccine types and relatively high prevalence of HPV-52 and -58 in our population. Our findings support universal "catch-up" vaccination of sexual experienced young women in Zhejiang Province, as well as enhance the hypothesis that the second-generation HPV prophylactic vaccines including HPV-52 and -58 may offer higher protection for women in China and other Asian areas. Furthermore, our data support close surveillance of perimenopausal women with HR-HPV infection.
\end{abstract}

\section{Background}

Papillomaviruses (PVs) comprise of a large group of non-enveloped double-stranded DNA viruses that infect a variety of vertebrate species, including humans. There are 16 genera of PVs and five of these genera, alpha, beta, gamma, mu and nu, are human papillomaviruses (HPVs). HPV infection may exist asymptomatically or induce the formation of benign or malignant lesions of human mucosal and cutaneous epithelia. HPV has been shown to be the etiologic agent of anogenital, especially cervical, cancers and a fraction of oropharyngeal

\footnotetext{
*Correspondence: xiex@zju.edu.cn

'Women's Reproductive Health Key Laboratory of Zhejiang Province; Department of Gynecologic Oncology, Women's Hospital, School of Medicine, Zhejiang University, Xueshi Rd\#2, Hangzhou, 310006, PR China
}

carcinomas. Other cancers causally linked to HPV include non-melanoma skin cancer and conjunctiva carcinoma [1,2]. More than 100 HPV genotypes have been molecularly characterized [1] and the types associated with anogenital cancers, which are of greatest medical importance, belong to the alpha-PV genus. According to International Agency for Research on Cancer working group, HPV-16, -18, -31, -33, -35, -39, -45, -51, -52, -56, -58 , and -59 were classified as "carcinogenic to humans", while HPV-6 and -11 were classified as "not classifiable as to its carcinogenicity to humans" [3].

Both the two available prophylactic HPV vaccines, the bivalent vaccine (Cervarix ${ }^{\oplus}$, GlaxoSmithKline Biologicals, targeted at HPV-16 and -18) and the quadrivalent vaccine (Gardasil', Merck, targeted at HPV-6, -11, -16 and 
-18), have shown prominently type-restricted prophylactic efficacy for genital lesions related to targeted types in women who were naive to the respective types at enrollment [4-7]. HPV vaccination also promises to decrease the incidence of other HPV-related cancers, as well as reduce the burden associated with the treatment of HPV-related benign lesions [8]. Since limited cross-protection would be offered between HPV types [9], heterogeneity in HPV type-specific distribution from different populations should be taken into account when predicting the effect of current prophylactic vaccines [10] and forming the basic for the second-generation vaccines targeted to specific regions.

Since March 2009, a randomized, double-blind trial testing the safety and efficacy of the quadrivalent vaccine (Gardasil ${ }^{\oplus}$, Merck) in Chinese women (V501-04100) was conducted in Zhejiang Province, a coastal region in southeast China. To the best of our knowledge, no epidemiologic data on HPV genotypes in general female population were reported from Zhejiang Province, which highlights the need for timely population-based study in this region. Due to the feasible anatomic site for sampling and the well-established sampling method for cervix, here, we investigated the cervical HPV infection in asymptomatic general female population to be conscious of the overall, type-specific and age-specific HPV prevalence, as well as determinants of HPV infection, in Zhejiang Province before large scale vaccination programs occur.

\section{Methods}

\section{Study population and inclusion criteria}

A total of 7500 women were randomly selected as candidates between November 2007 and August 2008 from the population list of five randomly chosen counties. These five counties are located in east, south, west, north and middle part of Zhejiang Province, respectively. In each county, one town and one village were randomly selected, and 1500 women (750 town and 750 village residents, respectively) were randomly recruited to ensure geographical and social diversity. A woman was eligible to be study objective if she: (a) was mentally and physically competent; (b) was aged between 20 and 79 years; (c) was a permanent resident of local area; (d) had no history of abnormal cytology or cervico-vaginal dysplasia; (e) had no abnormal vaginal bleeding and contact bleeding; (f) had no visual cervical lesions at simple visual inspection during gynecological examination; (g) had no history and associated symptoms of other HPV-related diseases; (h) was not a virgin; (i) was not presently pregnant; (j) had not undergone a total hysterectomy; (k) had no use of vaginal medication and no sexual intercourse in the previous three days. Eligible women were invited for a face-to-face interview and a gynecological examination in local hospitals.

Of these 7500 enumerated women, 247 stayed away from home at interview time, 376 did not meet the inclusion criteria, 317 could not undergo gynecological examination because of menstruation, and 1502 refused to participate mainly because they did not have enough time or did not think they needed gynecological examination in the absence of symptoms. Totally 5058 women were enrolled into the study.

All participants agreed to participate in the present study and signed informed consent forms. The study project was approved by The Human Research Ethical Committee of Women's Hospital, School of Medicine, Zhejiang University.

\section{Questionnaire interview}

An interviewer-administrated structured questionnaire was designed to collect information on socio-demographic characteristics, lifestyle, menstrual status, reproductive history, contraception and sexual behavior. Trained research nurses questioned participants face-toface in the local dialect of Chinese.

\section{Cervical specimen collection}

Samples of exfoliated cervical cells were collected with DNAPap cervical sampler (Digene) during gynecological examinations. The sampler was inserted $1-1.5 \mathrm{~cm}$ into the endocervical canal and rotated 3-5 full turns in counterclockwise direction. The tip containing cellular material was then placed into transport medium tube and stored at $4{ }^{\circ} \mathrm{C}$ immediately. All specimens were coded without knowledge of the subjects.

\section{HPV detection}

HPV DNA was extracted with phenol-chloroform, resuspended in $100 \mu \mathrm{L}$ elution buffer, and stored at -30176 ;C. The quality and integrity of sample DNA for polymerase chain reaction (PCR) was verified by amplification of a 268 base pair region of the human $\beta$-globin gene [11]. Specimens with negative internal control amplification were excluded. All the $\beta$-globin-positive samples were amplified with the MY09/11 L1 consensus primers of anogenital HPV genotypes [12] and synchronously detected with the commercially introduced HPV GenoArray Test kit (Hybribio). All the MY09/11 consensus PCR-positive/GenoArray-negative samples were typed with an improved PCR-restriction fragment length polymorphism (RFLP) assay validated by Hybrid Capture II and sequencing [13]. Approximately 7.5\% MY09/11 consensus PCR-positive/GenoArray-positive samples and 10\% MY09/11 consensus PCR-RFLP typed samples were randomly selected to be validated by sequencing. More than 5\% MY09/11 consensus PCR-negative/ 
GenoArray-negative samples were randomly selected to be validated by Real Time PCR HPV Detection Kit (Hybribio).

\section{$P C R$}

PCR was performed in $50 \mu \mathrm{L}$ reaction mixture containing $10 \times$ PCR buffer, $25 \mathrm{mM} \mathrm{MgCl}_{2}, 200 \mu \mathrm{M}$ deoxynucleotide triphosphate, $2 \mathrm{U}$ Taq polymerase, $10 \mathrm{pmol}$ of each primer, and $5 \mu \mathrm{L}$ template DNA. The PCR protocol was: preheating at $94^{\circ} \mathrm{C}$ for $7 \mathrm{~min}$, followed by 36 cycles of denaturation at $94^{\circ} \mathrm{C}$ for $45 \mathrm{sec}$, annealing at $56^{\circ} \mathrm{C}$ for $45 \mathrm{sec}$, and extension at $72^{\circ} \mathrm{C}$ for $45 \mathrm{sec}$, at last a final extension at $72^{\circ} \mathrm{C}$ for $10 \mathrm{~min}$. Products were identified by electrophoresis in $2.0 \%$ agarose gel stained with ethidium bromide. For every PCR assay, a negative control and a positive control (HPV DNA from SiHa) were run to control for possible contamination and accuracy.

\section{HPV GenoArray Test}

HPV GenoArray Test kit makes use of both DNA amplification and Hybribio's proprietary Flow-through Hybridization Technology to simultaneously identify 21 HPV genotypes: HPV-6, -11, -16, -18, -31, -33, -35, -39, $-42,-43,-44,-45,-51,-52,-53,-56,-58,-59,-66,-68$ and -81 (equivalent to CP8304). The test employs a gene chip with a nylon membrane onto which type-specific oligonucleotides probes have been immobilized. The final results were detected by colorimetric change on the chip under direct visualization. Test was performed according to the manufacture's instructions.

\section{Genotyping by RFLP}

The products generated by MY09/11 L1 consensus primers were typed with RFLP as described by Hong et al. [13].

\section{Sequencing}

MY09/11 consensus PCR-amplified products were sequenced in the 3730 ABI Prism sequencer (Applied Biosystems). The obtained sequences were compared to known HPV sequence databases (available at: http:// www.ncbi.nlm.nih.gov/BLAST/).

\section{Real Time PCR HPV Detection}

Real Time PCR HPV Detection kit detects 13 HPV types (HPV-16, -18, -31, -33, -35, -39, -45, -51, -52, -56, $-58,-59$ and -68$)$ in one single reaction by real-time PCR equipment. Test was performed according to the manufacture's instructions.

\section{Definition and estimation}

Positive result by any assay mentioned above was regarded as HPV positive. For samples inconsistent between HPV GenoArray Test and sequencing, the genotypes were identified according to sequencing. Multiple-type infection was separated into constituent types, thus type-specific prevalence included that in both single-type and multiple-type infection. Based on epidemiologic classification associated with cervical cancer, HPV $-16,-18,-31,-33,-35,-39,-45,-51,-52,-56$, -58 , and -59 were classified as established high-risk (HR) types, HPV-26, -53, -66, -68, -73 and -82 were classified as probably HR types, and HPV $-6,-11,-40$, $-42,-43,-44,-54,-61,-70,-72,-81$ and -89 (equivalent to CP6108) were classified as established low-risk (LR) types [1,3]. All other HPV types were considered as undetermined risk HPV types. Analyses were repeated by grouping HPV types according to phylogeny $[1,14]$.

\section{Statistical analysis}

Data were key-entered twice and analyzed using SPSS software for Windows (version 16.0). The $\chi^{2}$ test and, where appropriate, Fisher's exact test were used to compare HPV prevalence across age groups. Odds ratios (ORs) with 95\% confidence intervals (CIs) were calculated using unconditional logistic regression to estimate independent predictors for HPV infection. Analyses were performed for overall, established HR, established LR, single-type and multiple-type HPV infection, respectively. Age group and variables associated with HPV positivity in age-adjusted model were included as candidates in multivariate model. Final model was determined by forward elimination of candidate variables based on likelihood ratio tests. In all of the logistic models, HPVnegative women were used as the reference group. All hypotheses testing were two-sided. A level of 0.05 was chosen to indicate statistical significance.

\section{Results}

\section{HPV genotyping algorithm}

Of 5058 women who provided cervical cell samples, 71 were excluded because of negative $\beta$-globin. In the leaving 4987 samples, 615 (12.3\%) were HPV GenoArraypositive and 591 (11.9\%) were MY09/11 consensus PCRpositive. There was a $97.5 \%$ overall agreement between these two assays (kappa $=0.883 ; P<0.001$ ). Figure 1 shows the detailed HPV genotyping algorithm.

\section{Epidemiological distribution of HPV types}

In 4987 detected cervical samples, 665 (13.3\%) were HPV positive. The corresponding prevalence, age-standardized to the world population, were $13.5 \%$ overall. Of these 665 positive samples, 508 (76.4\%) were established HR-HPV and 176 (26.5\%) were multiple-type HPV infections. Totally 35 different genotypes, grouped in 11 alpha species, were identified. The five most prevalent types were HPV-52 (3.1\%), HPV-16 (2.5\%), HPV-58 (2.1\%), HPV-68 (1.0\%) and HPV-81 (0.9\%) (Table 1). Stratified with counties, the most prevalent types in east county were HPV-52 (37/1003, 3.7\%), HPV-58 (27/1003, 2.7\%), HPV-16 (17/1003, 1.7\%), HPV-68 (9/1003, 0.9\%), HPV -51 (7/1003, 0.7\%) and HPV -53 (7/1003, 0.7\%); in 


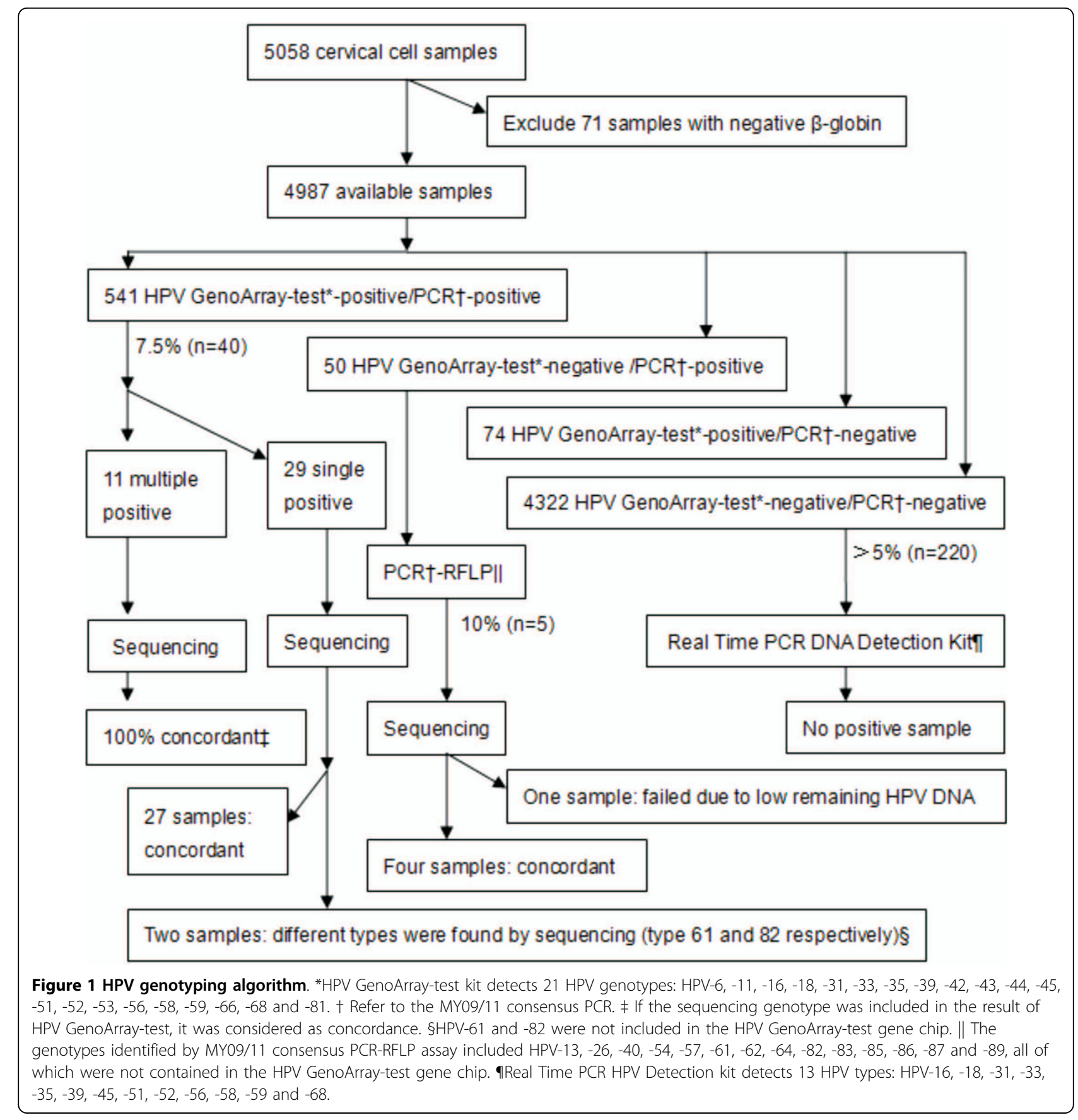

south county were HPV-52 (30/1045, 2.9\%), HPV-16 (25/1045, 2.4\%), HPV-68 (18/1045, 1.7\%), HPV-58 (17/ $1045,1.6 \%)$ and HPV-81 (16/1045, 1.5\%); in west county were HPV-52 (31/1042, 3.0\%), HPV-16 (25/1042, 2.4\%), HPV-31 (14/1042, 1.3\%), HPV-33 (12/1042, 1.2\%) and HPV-58 (12/1042, 1.2\%); in north county were HPV-58 (23/934, 2.5\%), HPV-16 (20/934, 2.1\%), HPV-52 (20/934, 2.1\%), HPV-81 (10/934, 1.1\%) and HPV-68 (9/934, $1.0 \%)$; in middle county were HPV-52 (37/963, 3.8\%), HPV-16 (36/963, 3.7\%), HPV-58 (27/963, 2.8\%), HPV-51
(15/963, 1.6\%) and HPV-81 (14/963, 1.5\%). The four most commonly detected HPV species were alpha-9, -7 , -6 and -3 (Table 1). HPV-16 or -18 were present in $3.1 \%$ of the detected samples, while only nine women $(0.2 \%)$ were infected with both HPV-16 and -18 . Totally 174 women $(3.5 \%)$ were positive for any of the vaccine types- $6,-11,-16$ and -18 , while no women were simultaneously positive for all these four types (Table 1).

The mean age of the detected women was 39.7 (range $20-79, \mathrm{SD}=8.9$ ) years. Figure 2 shows the age-specific 
Table 1 HPV prevalence for specific types and categories, both overall and by age group $(n=4987) *$.

\begin{tabular}{|c|c|c|c|c|c|c|c|c|c|c|}
\hline \multirow[b]{2}{*}{$\begin{array}{l}\text { Category, HPV type } \\
\text { (alpha species) }\end{array}$} & \multirow[b]{2}{*}{ No. } & \multirow[b]{2}{*}{$\begin{array}{c}\text { Overall } \\
\text { prevalence, } \%\end{array}$} & \multicolumn{8}{|c|}{ Prevalence by age group, $\%$} \\
\hline & & & $\begin{array}{c}20-24 \\
(n=117)\end{array}$ & $\begin{array}{c}25-29 \\
(n=526)\end{array}$ & $\begin{array}{c}30-34 \\
(\mathrm{n}=825)\end{array}$ & $\begin{array}{c}35-39 \\
(n=1102)\end{array}$ & $\begin{array}{c}40-44 \\
(n=1041)\end{array}$ & $\begin{array}{c}45-49 \\
(n=704)\end{array}$ & $\begin{array}{c}50-54 \\
(n=368)\end{array}$ & $\begin{array}{c}55-79 \\
(n=304) \\
\end{array}$ \\
\hline Any type & 665 & 13.3 & 16.2 & 12.9 & 11.0 & 13.9 & 13.6 & 13.2 & 17.7 & 11.2 \\
\hline \multicolumn{11}{|l|}{ Established HR types } \\
\hline $\begin{array}{l}\text { Any established HR } \\
\text { types }\end{array}$ & 508 & 10.2 & 14.5 & 9.3 & 8.4 & 10.7 & 10.7 & 9.2 & 14.4 & 8.6 \\
\hline 16 (alpha-9) & 123 & 2.5 & 1.7 & 2.5 & 2.2 & 2.4 & 2.1 & 2.8 & 4.1 & 2.3 \\
\hline 18 (alpha-7) & 39 & 0.8 & 0.9 & 0.6 & 0.8 & 0.9 & 1.2 & 0.4 & 0.5 & 0.3 \\
\hline 31 (alpha-9) & 39 & 0.8 & 1.7 & 1.0 & 0.4 & 1.3 & 0.5 & 0.4 & 0.8 & 1.3 \\
\hline 33 (alpha-9) & 38 & 0.8 & 2.6 & 1.0 & 0.6 & 0.7 & 0.7 & 0.4 & 1.4 & 0.7 \\
\hline 35 (alpha-9) & 9 & 0.2 & 0.9 & 0.0 & 0.4 & 0.0 & 0.1 & 0.1 & 0.5 & 0.3 \\
\hline 39 (alpha-7) & 13 & 0.3 & 0.0 & 0.2 & 0.4 & 0.1 & 0.4 & 0.0 & 0.0 & 1.3 \\
\hline 45 (alpha-7) & 16 & 0.3 & 0.9 & 0.8 & 0.2 & 0.1 & 0.4 & 0.4 & 0.0 & 0.3 \\
\hline 51 (alpha-5) & 46 & 0.9 & 0.0 & 1.3 & 1.0 & 0.5 & 0.6 & 0.6 & 2.2 & 2.3 \\
\hline 52 (alpha-9) & 155 & 3.1 & 3.4 & 2.1 & 2.7 & 3.4 & 3.8 & 3.3 & 3.3 & 2.0 \\
\hline 56 (alpha-6) & 21 & 0.4 & 1.7 & 0.4 & 0.1 & 0.2 & 0.4 & 0.6 & 1.1 & 0.7 \\
\hline 58 (alpha-9) & 106 & 2.1 & 3.4 & 2.3 & 1.8 & 1.9 & 2.0 & 1.8 & 3.5 & 2.3 \\
\hline 59 (alpha-7) & 33 & 0.7 & 0.0 & 1.1 & 0.6 & 1.0 & 0.2 & 0.3 & 1.1 & 1.0 \\
\hline \multicolumn{11}{|l|}{ Probably HR types } \\
\hline Any probably HR types & 120 & 2.4 & 4.3 & 3.2 & 1.3 & 2.4 & 1.6 & 3.1 & 4.1 & 2.3 \\
\hline 26 (alpha-5) & 3 & 0.1 & 0.0 & 0.2 & 0.0 & 0.0 & 0.1 & 0.0 & 0.3 & 0.0 \\
\hline 53 (alpha-6) & 39 & 0.8 & 2.6 & 0.6 & 0.6 & 0.7 & 0.5 & 0.7 & 1.4 & 1.6 \\
\hline 66 (alpha-6) & 27 & 0.5 & 0.0 & 1.3 & 0.1 & 0.5 & 0.3 & 0.9 & 0.8 & 0.3 \\
\hline 68 (alpha-7) & 52 & 1.0 & 1.7 & 1.1 & 0.5 & 1.2 & 0.8 & 1.7 & 1.6 & 0.3 \\
\hline 82 (alpha-5) & 2 & 0.0 & 0.0 & 0.0 & 0.1 & 0.0 & 0.1 & 0.0 & 0.0 & 0.0 \\
\hline \multicolumn{11}{|l|}{ Established LR types } \\
\hline $\begin{array}{l}\text { Any established LR } \\
\text { types }\end{array}$ & 137 & 2.7 & 2.6 & 2.3 & 2.3 & 2.7 & 2.8 & 2.3 & 4.3 & 3.9 \\
\hline 6 (alpha-10) & 10 & 0.2 & 0.0 & 0.2 & 0.2 & 0.0 & 0.2 & 0.0 & 0.0 & 1.6 \\
\hline 11 (alpha-10) & 11 & 0.2 & 0.0 & 0.2 & 0.4 & 0.3 & 0.2 & 0.0 & 0.3 & 0.3 \\
\hline 40 (alpha-8) & 1 & 0.0 & 0.0 & 0.2 & 0.0 & 0.0 & 0.0 & 0.0 & 0.0 & 0.0 \\
\hline 42 (alpha-1) & 22 & 0.4 & 1.7 & 0.4 & 0.4 & 0.3 & 0.5 & 0.3 & 0.5 & 1.0 \\
\hline 43 (alpha-8) & 14 & 0.3 & 0.0 & 0.0 & 0.2 & 0.5 & 0.4 & 0.1 & 0.5 & 0.0 \\
\hline 44 (alpha-10) & 29 & 0.6 & 0.0 & 0.6 & 0.4 & 0.7 & 0.9 & 0.6 & 0.5 & 0.0 \\
\hline 54 (alpha-13) & 1 & 0.0 & 0.0 & 0.2 & 0.0 & 0.0 & 0.0 & 0.0 & 0.0 & 0.0 \\
\hline 61 (alpha-3) & 8 & 0.2 & 0.0 & 0.2 & 0.2 & 0.1 & 0.0 & 0.3 & 0.5 & 0.0 \\
\hline 81 (alpha-3) & 46 & 0.9 & 0.9 & 0.4 & 0.5 & 1.0 & 0.8 & 1.1 & 2.2 & 1.3 \\
\hline 89 (alpha-3) & 2 & 0.0 & 0.0 & 0.0 & 0.1 & 0.1 & 0.0 & 0.0 & 0.0 & 0.0 \\
\hline \multicolumn{11}{|l|}{ Undetermined types } \\
\hline $\begin{array}{l}\text { Any undetermined } \\
\text { types }\end{array}$ & 13 & 0.3 & 0.0 & 0.2 & 0.6 & 0.3 & 0.2 & 0.3 & 0.0 & 0.0 \\
\hline 13 (alpha-10) & 1 & 0.0 & 0.0 & 0.0 & 0.0 & 0.1 & 0.0 & 0.0 & 0.0 & 0.0 \\
\hline 57 (alpha-4) & 2 & 0.0 & 0.0 & 0.0 & 0.0 & 0.1 & 0.1 & 0.0 & 0.0 & 0.0 \\
\hline 62 (alpha-3) & 4 & 0.1 & 0.0 & 0.0 & 0.2 & 0.0 & 0.0 & 0.3 & 0.0 & 0.0 \\
\hline 64 (alpha-11) & 1 & 0.0 & 0.0 & 0.2 & 0.0 & 0.0 & 0.0 & 0.0 & 0.0 & 0.0 \\
\hline 83 (alpha-3) & 1 & 0.0 & 0.0 & 0.0 & 0.0 & 0.1 & 0.0 & 0.0 & 0.0 & 0.0 \\
\hline 85 (alpha-7) & 1 & 0.0 & 0.0 & 0.0 & 0.0 & 0.0 & 0.1 & 0.0 & 0.0 & 0.0 \\
\hline 86 (alpha-3) & 1 & 0.0 & 0.0 & 0.0 & 0.1 & 0.0 & 0.0 & 0.0 & 0.0 & 0.0 \\
\hline 87 (alpha-3) & 2 & 0.0 & 0.0 & 0.0 & 0.2 & 0.0 & 0.0 & 0.0 & 0.0 & 0.0 \\
\hline
\end{tabular}


Table 1: HPV prevalence for specific types and categories, both overall and by age group $(\mathbf{n}=\mathbf{4 9 8 7}) *$. (Continued)

\begin{tabular}{|c|c|c|c|c|c|c|c|c|c|c|}
\hline \multicolumn{11}{|l|}{ Vaccine types } \\
\hline 16 or 18 & 153 & 3.1 & 2.6 & 2.7 & 2.8 & 3.1 & 3.1 & 3.1 & 4.6 & 2.6 \\
\hline $16+18$ & 9 & 0.2 & 0.0 & 0.4 & 0.2 & 0.2 & 0.2 & 0.1 & 0.0 & 0.0 \\
\hline Single-type infections & 489 & 9.8 & 12.0 & 9.3 & 7.9 & 10.7 & 10.7 & 10.4 & 10.9 & 6.2 \\
\hline Multiple-type infections & 176 & 3.5 & 4.3 & 3.6 & 3.2 & 3.2 & 3.0 & 2.8 & 6.8 & 4.9 \\
\hline Alpha-1 type infections & 22 & 0.4 & 1.7 & 0.4 & 0.4 & 0.3 & 0.5 & 0.3 & 0.5 & 1.0 \\
\hline Alpha-3 type infections & 62 & 1.2 & 0.9 & 0.6 & 1.5 & 1.2 & 0.8 & 1.7 & 2.4 & 1.3 \\
\hline Alpha-4 type infections & 2 & 0.0 & 0.0 & 0.0 & 0.0 & 0.1 & 0.1 & 0.0 & 0.0 & 0.0 \\
\hline Alpha-5 type infections & 51 & 1.0 & 0.0 & 1.5 & 1.1 & 0.5 & 0.8 & 0.6 & 2.4 & 2.3 \\
\hline Alpha- 6 type infections & 81 & 1.6 & 3.4 & 2.3 & 0.8 & 1.4 & 1.1 & 2.0 & 3.0 & 2.3 \\
\hline Alpha-7 type infections & 147 & 2.9 & 3.4 & 3.6 & 2.3 & 3.2 & 2.9 & 2.6 & 3.3 & 3.3 \\
\hline Alpha-8 type infections & 15 & 0.3 & 0.0 & 0.2 & 0.2 & 0.5 & 0.4 & 0.1 & 0.5 & 0.0 \\
\hline Alpha-10 type infections & 51 & 1.0 & 0.0 & 1.0 & 1.0 & 1.1 & 1.2 & 0.6 & 0.8 & 2.0 \\
\hline Alpha-11 type infections & 1 & 0.0 & 0.0 & 0.2 & 0.0 & 0.0 & 0.0 & 0.0 & 0.0 & 0.0 \\
\hline Alpha-13 type infections & 1 & 0.0 & 0.0 & 0.2 & 0.0 & 0.0 & 0.0 & 0.0 & 0.0 & 0.0 \\
\hline
\end{tabular}

HPV: human papillomavirus, No.: number, HR: high-risk, LR: low-risk

*The prevalence of an individual type or category included detection of this type or category in both single- and multiple-type infection.

prevalence for categories of HPV infection. There were two peaks of established HR-HPV infection. The first was $14.5 \%$ in women $20-24$ years old and the second was $14.4 \%$ in women $50-54$ years old $\left(\chi^{2}=15.166, P=\right.$ 0.034) (Figure 1A). Similar pattern was observed for probably HR-HPV infection $\left(\chi^{2}=15.901, P=0.026\right)$, while overall and established LR-HPV infection showed relatively flat curves $\left(\chi^{2}=12.284, P=0.092\right.$ and $\chi^{2}=$ $6.821, P=0.448$, respectively) (Figure $1 \mathrm{~A})$. The age-specific curves for alpha-9 $\left(\chi^{2}=12.998, P=0.072\right)$ and -6 $\left(\chi^{2}=15.214, P=0.033\right)$ were similar to the established HR and probably HR-HPV infection, with two peaks, while the curves for alpha-7 $\left(\chi^{2}=2.944, P=0.890\right)$ and $3\left(\chi^{2}=9.898, P=0.194\right)$ were more flat (Figure $\left.1 \mathrm{~B}\right)$. The prevalence for HPV-16 or-18 and for HPV-6, -11, -16 or -18 showed no significant differences across age groups.

\section{Risk profile for HPV Infection}

In age-adjusted models, no significant associations were found between HPV positivity and smoking, income, age at menarche, age at marriage, reproductive history, condom or intrauterine device use as the main contraceptive method in the recent two years, history of malignancy, history of subtotal hysterectomy and history of Papanicolaou screening (data not shown). In multivariate models, marital status, residence, passive smoking, menstrual cycle, outcome of initial pregnancy, oral contraceptive use as the main contraceptive method in the recent two years, age at sexual initiation and lifetime number of sexual partners were eliminated from the final models. The independent predictors for overall, established HR, established LR, single-type and multiple-type HPV infection were listed in Table 2, respectively. Partner's lifetime number of partners was the only shared predictor for all categories of HPV infection (Table 2).

\section{Discussion}

To date, no type-specific HPV testing is approved by the Food and Drug Administration or is used widely. HPV GenoArray-test, which has already been used for quite a while in European and Asian countries, showed high level agreement (97.5\%) with MY09/11 consensus PCR system. The concordance of HPV GenoArray-test with Amplicor HPV test [15] or Roche Linear Array [16] was also reported to be excellent. Considering that HPV GenoArray-test could not identify genotypes not included in gene chip, we utilized an improved PCRRFLP technique for the MY09/11 consensus PCR-positive/GenoArray-negative samples.

Compared with similar studies in China, age-standardized HPV prevalence estimation in Zhejiang Province (13.5\%) was similar to that in a central rural area of China (14.2\%) [17], but lower than that in the largest city in northeast China (16.6\%) [18] and an urban city in south China (17.6\%) [19]. Although 1502 women refused to participate, it may not cause large bias as HPV infection is asymptomatic. HPV prevalence in women without cervical abnormalities was estimated to between $1.4 \%$ to $25.6 \%$ by country, and varied from $1.6 \%$ to $14.2 \%$ in Asia countries [10]. The population in our study was asymptomatic women with no history of cervical neoplasia or other HPV-related diseases. Based 

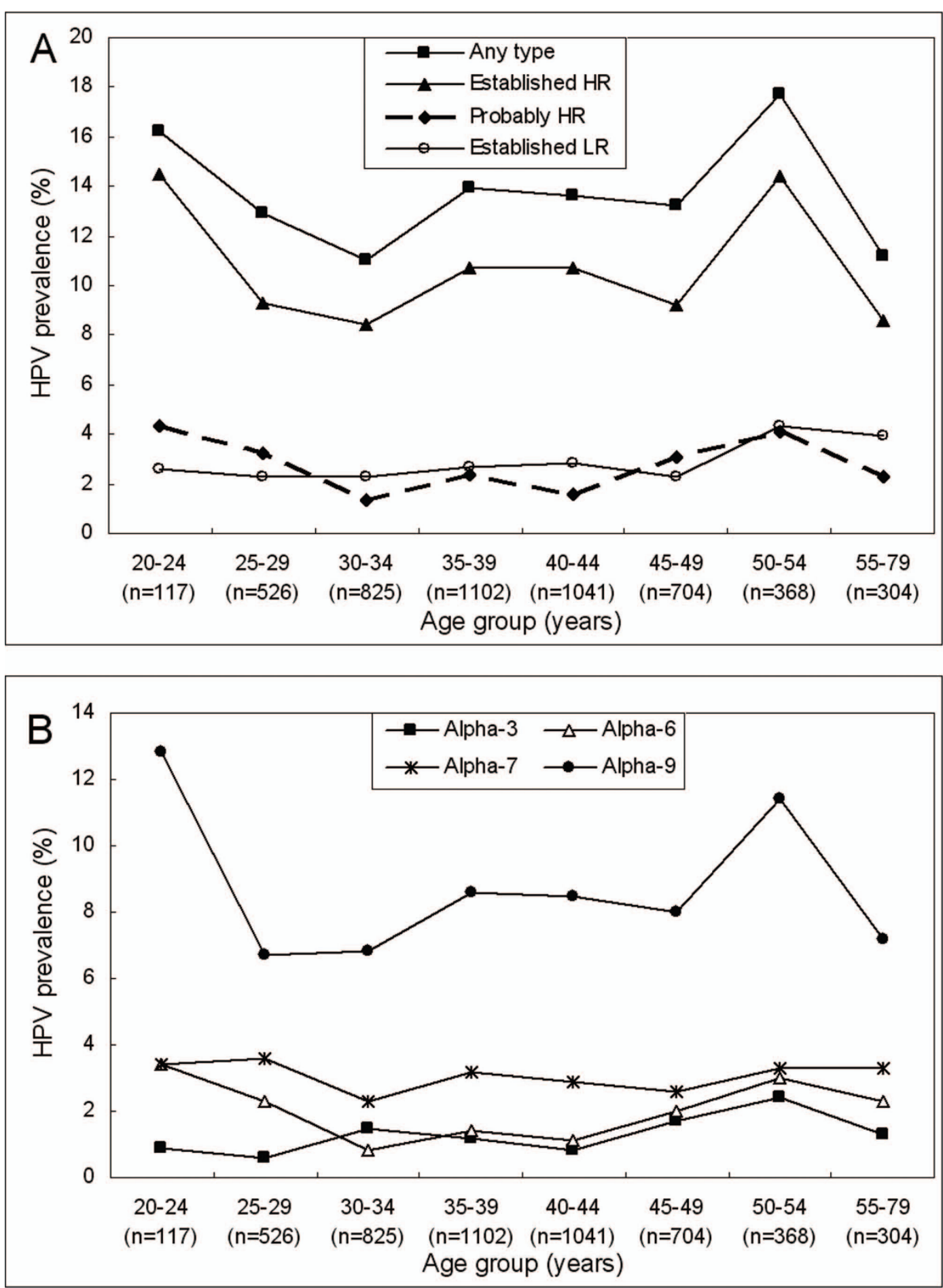

Figure 2 Age-specific prevalence of HPV infection in general female population in Zhejiang Province, southeast China. (A) Overall HPV, established high-risk (HR) HPV, probably HR-HPV and established low-risk (LR) HPV. Established HR-HPV types included HPV-16, -18, $-31,-33,-35,-39,-45,-51,-52,-56,-58$ and -59 ; probably HR-HPV types included HPV-26, -53, -66, -68, -73 and -82; established LR-HPV types included HPV-6, -11, -40,-42,-43,-44,-54,-61, -70, -72, -81 and -89 (equivalent to CP6108). (B) Alpha-3, -6, -7 and -9 species. Alpha-3 species included HPV-61, -62, -72, -81, -83, -84, -86, -87 and -89; alpha-6 species included HPV-30, -53, -56 and -66; alpha-7 species included HPV-18, -39, $-45,-59,-68-70$ and -85 ; alpha-9 species included HPV-16, $-31,-33,-35,-52,-58$ and -67 . The prevalence of an individual category included detection of this category in both single-type and multiple-type infection. 
Table 2 Multivariate OR and $95 \% \mathrm{Cl}$ for predictors of different categories of HPV infection*.

\begin{tabular}{|c|c|c|c|c|c|c|}
\hline \multirow[b]{2}{*}{ Characteristics } & \multirow[b]{2}{*}{ No.t } & \multicolumn{5}{|c|}{ Multivariate OR $(95 \% \mathrm{Cl})$ for HPV infection $\neq$} \\
\hline & & $\begin{array}{l}\text { Any-type } \\
\text { HPV infection }\end{array}$ & $\begin{array}{l}\text { Established HR- } \\
\text { HPV infection }\end{array}$ & $\begin{array}{l}\text { Established LR- } \\
\text { HPV infection }\end{array}$ & $\begin{array}{l}\text { Single-type } \\
\text { HPV infection }\end{array}$ & $\begin{array}{l}\text { Multiple-type } \\
\text { HPV infection }\end{array}$ \\
\hline \multicolumn{7}{|l|}{ Age (years) } \\
\hline $20-24$ & 117 & & $2.02(0.99-4.10)$ & & & $0.85(0.30-2.41)$ \\
\hline $25-29$ & 526 & & $1.16(0.69-1.96)$ & & & $0.71(0.35-1.42)$ \\
\hline $30-34$ & 825 & & $1.09(0.66-1.77)$ & & & $0.62(0.32-1.19)$ \\
\hline $35-39$ & 1102 & & $1.48(0.94-2.34)$ & & & $0.64(0.34-1.19)$ \\
\hline $40-44$ & 1041 & & $1.40(0.88-2.21)$ & & & $0.61(0.32-1.15)$ \\
\hline $45-49$ & 704 & & $1.16(0.72-1.89)$ & & & $0.57(0.29-1.14)$ \\
\hline $50-54$ & 368 & & $1.93(1.16-3.19) \|$ & & & $1.42(0.73-2.76)$ \\
\hline $55-79$ & 304 & & Ref & & & Ref \\
\hline$P$ for trend & & & 0.035 & & & 0.041 \\
\hline \multicolumn{7}{|l|}{ Occupation } \\
\hline Farmer & 644 & $1.24(0.92-1.67)$ & $1.21(0.87-1.70)$ & & $1.39(0.99-1.95)$ & \\
\hline White collar & 1246 & $1.29(1.01-1.65) \|$ & $1.18(0.89-1.56)$ & & $1.43(1.08-1.90) \|$ & \\
\hline Businesswoman & 422 & $1.28(0.91-1.80)$ & $1.28(0.87-1.87)$ & & $1.53(1.05-2.24) \|$ & \\
\hline Unemployed & 1209 & 1.74(1.38-2.20)\# & 1.82(1.40-2.38)\# & & 1.88(1.43-2.47)\# & \\
\hline Blue collar labor & 1388 & Ref & Ref & & Ref & \\
\hline \multicolumn{7}{|l|}{ Education level } \\
\hline Under middle school & 1589 & & & Ref & & \\
\hline Middle school & 2812 & & & $0.61(0.41-0.92) \|$ & & \\
\hline University or above & 582 & & & $1.15(0.66-2.02)$ & & \\
\hline \multicolumn{7}{|l|}{ Residence of partner } \\
\hline Urban & 1623 & & & $1.61(1.08-2.41) \|$ & & \\
\hline Rural & 3343 & & & Ref & & \\
\hline \multicolumn{7}{|l|}{ Ever use of OC } \\
\hline Former or Current & 900 & $1.28(1.04-1.58) \|$ & $1.46(1.16-1.84) 9$ & & & \\
\hline Never & 4087 & Ref & Ref & & & \\
\hline \multicolumn{7}{|l|}{ Partner's No. of partners§ } \\
\hline 1 & 4736 & Ref & Ref & Ref & Ref & Ref \\
\hline$\geq 2$ & 170 & 2.72(1.89-3.90)\# & 2.42(1.59-3.69)\# & $3.16(1.65-6.04) 9$ & 2.83(1.90-4.22)\# & $2.71(1.49-4.95) \emptyset$ \\
\hline
\end{tabular}

OR: Odds ratio, Cl: Confidence interval, HPV: human papillomavirus, No.: number, HR: high-risk, LR: low-risk, OC, oral contraceptive, Ref: reference *The reference group was HPV-negative women.

† Numbers did not always add up to total due to missing data.

₹ Age group and variables associated with HPV infection in respective age-adjusted model were included as candidates in respective multivariate model. Final modals were determined by forward elimination of candidate variables based on likelihood ratio tests.

§Refers to partner's lifetime number of partners.

$\| P<0.05$.

IP $<0.01$.

\#P $<0.001$.

on cost constraints, we did not perform the Bethesda System Terminology based cytology for participants in this study. On the one hand, it may actually help better estimate HPV burden in the general female population in this region. On the other hand, inclusion of women with abnormal cytology (mainly mild ones) did not materially affect significant findings [10,19-21], which made our findings comparable with other investigations.

The five most common HPV types in general female population worldwide were HPV-16, -18, $-31,-58$ and -52 , while the rank varied by region [22]. Contrasting to most previous surveys in China [17-19] and other populations [22], HPV-52, rather than HPV-16, was the most commonly identified type in our population, consistent with the data from Japan and Taiwan and eastern Africa [22]. HPV-16 ranked the second and the prevalence $(2.5 \%)$ was comparable with that worldwide [22]. HPV-58, another common type in Asian population $[23,24]$, ranked the third (15.9\% of all infections), similar to that in South Taiwan (19.9\% of all infections in general population) [24]. The finding that HPV-52 was more prevalent than HPV-16 may be due to the geographical and biological interplay between HPV types or variants and host immunogenic factors [25]. Another 
interpretation attributed to the genotyping system. On the one hand, with HPV GenoArray-test kit, Lin et al. [26] found that HPV-52 and -58 were the most prevalent genotypes in Chinese women in Guangdong Province, while Grisaru et al. [15] found the relatively high percentage of HPV-52 in Israeli Jewish women referred for colposcopic examination. On the other hand, Liu et al. [16] reported that HPV GenoArray-test had an analytical sensitivity in detection of HPV-16 and -18 in as few as 10-50 copies. Larger and comprehensive studies are warranted to further evaluate the performance of HPV GenoArray-test, however, the preponderance of HPV -52 and -58 in our study population is meaningful. As accumulated studies had shown that HPV -52 and -58 were more predominant in Asian populations [10,17-19,27] and overrepresented in cervical cancer cases from eastern and southeastern Asia [13,28,29], we assume that the second-generation HPV prophylactic vaccines including HPV-52 and -58 may offer higher protection for women in China and other Asian areas.

For the current available prophylactic vaccines, the prevalence of vaccine types was consistently low across age groups. Since a proportion of older women might have already been infected and cleared previous infections, the actually exposed rate to vaccine types might be higher than observed in older women. Considering that HPV prophylactic vaccines do not have clinical benefit in women who have been infected with vaccine types at the time of vaccination, we assume that younger women would draw more benefit from "catch-up" HPV vaccination programs.

Bimodal age distribution of HR-HPV, which was not common in mainland China $[17,18,26]$, was observed in the current study. Viral prevalence is the product of incidence, persistence and clearance of infection. As HPV is often acquired soon after sexual initiation [30], the actual first peak of HR-HPV infection might before 20 years old, due to the higher probability of exposure to new HPV infections and the lack of adaptive immune responses in younger women. The second peak observed in perimenopausal women may be partly explained by viral persistence or reactivation of latent HPV due to the physiologic and immunologic dysregulation caused by hormone fluctuations at menopausal transition [31]. Another interpretation attributes to changes in the sexual behavior of women or their partners in middle age. Considering that only HR-HPV, which had a higher tendency to cause persistent infection [32,33], showed the second peak around menopause, we assume that persistence or reactivation of latent HPV may better explain the second peak in our population. Castle et al. also suggested a stronger role for viral persistence than for acquisition of new infections in women aged 45 years or older in Costa Rica [34]. Accordingly, HR-HPV positivity around the age of menopause implies more possibility of viral persistence, which makes HPV screening have more important clinical meaning for perimenopausal women than for young women. For perimenopausal women with positive HR-HPV, further evaluation, including cytology and even colposcopy, should be considered and regular screening should be prolonged because they have higher risk for the development of cervical cancer.

Alpha-6, -7, -9 species comprised mainly of established HR and probably HR-HPV types, while alpha-3 species comprised mainly of established LR-HPV types. However, alpha-7 species were more closely genetically related to alpha-3 than to alpha-9 species [35]. Consistently, the age-related curves for alpha-7 and alpha-3 species were similar. The difference of age curves between alpha-3/7 species and alpha- $6 / 9$ species may be a reflection for different tropisms for cervical columnar epithelium. According to Castle et al., the age-related changes in cervix influence HPV type-specific detection at the cervical os, where cervical specimens are routinely collected [35]. What is more, diverse patterns also exist among different populations with regard to the same species $[21,35]$. Whether it is due to the diversity in the physiologic change of cervix among different populations, or it could be explained by variants which may have subtle differences in tropism and other biological behaviors, is unclear.

We also explored the independent predictors for categories of HPV positivity. Previous studies showed that high-risk sexual behavior, including early sexual initiation, multiple sexual partners and sexual partner as an HPV carrier, was the pivotal determinant for HPV infection among women [36-38]. However, less independent indicators related with sexual behavior was found in our study, except for partner's lifetime number of partners, which might be due to traditional habitude, especially in oriental countries. Furthermore, our finding suggest that in areas where women's sexual conception and behavior are conservative, men possessing multiple sexual partners may be a predominant resource for HPV positivity in women as long as HPV is mainly transmitted through sexual intercourse [39].

\section{Conclusions}

This study provides a unique opportunity to gather baseline data on cervical HPV prevalence, as well as predictors concerned, in general female population in Zhejiang Province, southeast China. The data showed low prevalence of HPV vaccine types and relatively high prevalence of HPV-52 and -58. Our findings support universal "catch-up" vaccination of sexual experienced young women in this region, as well as enhance the hypothesis that the second-generation HPV prophylactic 
vaccines including HPV-52 and -58 may offer higher protection for women in China and other Asian areas. Furthermore, our data also support close surveillance of perimenopausal women with HR-HPV infection.

\author{
Abbreviations \\ PV: papillomavirus; HPV: human papillomavirus; HR: high-risk; LR: low-risk; \\ PCR: polymerase chain reaction; RFLP: restriction fragment length \\ polymorphism; OR: odds ratio; Cl: confidence interval.
}

\section{Acknowledgements}

We sincerely thank all the staff and participants who took part in this study. We also thank Hybribio Company for its technical support of HPV GenoArray test and Real Time PCR HPV Detection. This work was funded by National Funds from the Ministry of Health (WKJ2007-3-001) and Scientific and Technologic Grant of Zhejiang Province (No: 2006C13080).

\section{Author details}

${ }^{1}$ Women's Reproductive Health Key Laboratory of Zhejiang Province, Women's Hospital, School of Medicine, Zhejiang University, Xueshi Rd\#2, Hangzhou, 310006, PR China. ${ }^{2}$ Women's Reproductive Health Key Laboratory of Zhejiang Province; Department of Gynecologic Oncology, Women's Hospital, School of Medicine, Zhejiang University, Xueshi Rd\#2, Hangzhou, 310006, PR China.

\section{Authors' contributions}

JY carried out the study, performed analysis of data and drafted the manuscript. XDC participated in the study design and coordination. XJC carried out the MY09/11 consensus PCR and the PCR-RFLP assays. FY contributed to study design and developed the assay protocol. WGL participated in the study design, sample collection and coordination. XX conceived the study, provided consultation and revised the manuscript. All authors have read and approved the final manuscript.

\section{Competing interests}

The authors declare that they have no competing interests.

Received: 3 January 2010 Accepted: 23 March 2010

Published: 23 March 2010

\section{References}

1. Munoz N, Castellsague X, de Gonzalez AB, Gissmann L: Chapter 1: HPV in the etiology of human cancer. Vaccine 2006, 24(Suppl 3):1-10.

2. Trottier $H$, Burchell AN: Epidemiology of mucosal human papillomavirus infection and associated diseases. Public Health Genomics 2009, 12:291-307.

3. Bouvard V, Baan R, Straif K, Grosse Y, Secretan B, El Ghissassi F, BenbrahimTallaa L, Guha N, Freeman C, Galichet L, Cogliano V: A review of human carcinogens-Part B: biological agents. Lancet Oncol 2009, 10:321-322.

4. Paavonen J, Jenkins D, Bosch FX, Naud P, Salmeron J, Wheeler CM, Chow SN, Apter DL, Kitchener HC, Castellsague X, de Carvalho NS, Skinner SR, Harper DM, Hedrick JA, Jaisamrarn U, Limson GA, Dionne M, Quint W, Spiessens B, Peeters P, Struyf F, Wieting SL, Lehtinen MO, Dubin G: Efficacy of a prophylactic adjuvanted bivalent $\mathrm{L} 1$ virus-like-particle vaccine against infection with human papillomavirus types 16 and 18 in young women: an interim analysis of a phase III double-blind, randomised controlled trial. Lancet 2007, 369:2161-2170.

5. Garland SM, Hernandez-Avila M, Wheeler CM, Perez G, Harper DM, Leodolter S, Tang GW, Ferris DG, Steben M, Bryan J, Taddeo FJ, Railkar R, Esser MT, Sings HL, Nelson M, Boslego J, Sattler C, Barr E, Koutsky LA: Quadrivalent vaccine against human papillomavirus to prevent anogenital diseases. N Engl J Med 2007, 356:1928-1943.

6. Kjaer SK, Sigurdsson K, Iversen OE, Hernandez-Avila M, Wheeler CM, Perez G, Brown DR, Koutsky LA, Tay EH, Garcia P, Ault KA, Garland SM, Leodolter S, Olsson SE, Tang GW, Ferris DG, Paavonen J, Lehtinen M, Steben M, Bosch FX, Dillner J, Joura EA, Majewski S, Munoz N, Myers ER, Villa LL, Taddeo FJ, Roberts C, Tadesse A, Bryan J, Maansson R, Lu S, Vuocolo S, Hesley TM, Saah A, Barr E, Haupt RM: A pooled analysis of continued prophylactic efficacy of quadrivalent human papillomavirus (Types 6/11/
16/18) vaccine against high-grade cervical and external genital lesions. Cancer Prev Res (Phila Pa) 2009, 2:868-878.

7. Munoz N, Manalastas R Jr, Pitisuttithum P, Tresukosol D, Monsonego J, Ault K, Clavel C, Luna J, Myers E, Hood S, Bautista O, Bryan J, Taddeo FJ, Esser MT, Vuocolo S, Haupt RM, Barr E, Saah A: Safety, immunogenicity, and efficacy of quadrivalent human papillomavirus (types $6,11,16,18$ ) recombinant vaccine in women aged 24-45 years: a randomised, double-blind trial. Lancet 2009, 373:1949-1957.

8. Goldie SJ, O'Shea M, Campos NG, Diaz M, Sweet S, Kim SY: Health and economic outcomes of HPV 16, 18 vaccination in 72 GAVI-eligible countries. Vaccine 2008, 26:4080-4093.

9. Herrero R: Human papillomavirus (HPV) vaccines: limited cross-protection against additional HPV types. J Infect Dis 2009, 199:919-922.

10. Clifford GM, Gallus S, Herrero R, Munoz N, Snijders PJ, Vaccarella S, Anh PT, Ferreccio C, Hieu NT, Matos E, Molano M, Rajkumar R, Ronco G, de Sanjose S, Shin HR, Sukvirach S, Thomas JO, Tunsakul S, Meijer CJ, Franceschi S: Worldwide distribution of human papillomavirus types in cytologically normal women in the International Agency for Research on Cancer HPV prevalence surveys: a pooled analysis. Lancet 2005, 366:991-998

11. Saiki RK, Chang CA, Levenson CH, Warren TC, Boehm CD, Kazazian HH Jr, Erlich HA: Diagnosis of sickle cell anemia and betathalassemia with enzymatically amplified DNA and nonradioactive allele-specific oligonucleotide probes. $N$ Engl J Med 1988, 319:537-541.

12. Manos MM, Ting Y, Wright DK, Lewis AJ, Broker TR, Wolinsky SM: Use of polymerase chain reaction amplification for the detection of genital human papillomaviruses. Cancer Cells 1989, 7:209-214.

13. Hong D, Ye F, Chen H, Lu W, Cheng Q, Hu Y, Xie X: Distribution of human papillomavirus genotypes in the patients with cervical carcinoma and its precursors in Zhejiang Province, China. Int I Gynecol Cancer 2008, 18:104-109.

14. de Villiers EM, Fauquet C, Broker TR, Bernard HU, zur Hausen H: Classification of papillomaviruses. Virology 2004, 324:17-27.

15. Grisaru D, Avidor B, Niv J, Marmor S, Almog B, Leibowitz C, Graidy M, Giladi M: Pilot study of prevalence of high-risk human papillomavirus genotypes in Israeli Jewish women referred for colposcopic examination. J Clin Microbiol 2008, 46:1602-1605.

16. Liu SS, Leung RC, Chan KK, Cheung AN, Ngan HY: Evaluation of a newly developed GenoArray human papillomavirus (HPV) genotyping assay by comparison with Roche Linear Array HPV genotyping assay. J Clin Microbiol 2009.

17. Dai M, Bao YP, Li N, Clifford GM, Vaccarella S, Snijders PJ, Huang RD, Sun LX, Meijer CJ, Qiao YL, Franceschi S: Human papillomavirus infection in Shanxi Province, People's Republic of China: a population-based study. Br J Cancer 2006, 95:96-101.

18. Li LK, Dai M, Clifford GM, Yao WQ, Arslan A, Li N, Shi JF, Snijders PJ, Meijer CJ, Qiao YL, Franceschi S: Human papillomavirus infection in Shenyang City, People's Republic of China: A population-based study. $\mathrm{Br}$ J Cancer 2006, 95:1593-1597.

19. Wu RF, Dai M, Qiao YL, Clifford GM, Liu ZH, Arslan A, Li N, Shi JF, Snijders PJ, Meijer CJ, Franceschi S: Human papillomavirus infection in women in Shenzhen City, People's Republic of China, a population typical of recent Chinese urbanisation. Int I Cancer 2007, 121:1306-1311.

20. Coupe VM, Berkhof J, Bulkmans NW, Snijders PJ, Meijer CJ: Age-dependent prevalence of 14 high-risk HPV types in the Netherlands: implications for prophylactic vaccination and screening. Br J Cancer 2008, 98:646-651

21. Chan PK, Ho WC, Wong MC, Chang AR, Chor JS, Yu MY: Epidemiologic risk profile of infection with different groups of human papillomaviruses. J Med Virol 2009, 81:1635-1644

22. de Sanjose S, Diaz M, Castellsague X, Clifford G, Bruni L, Munoz N, Bosch FX: Worldwide prevalence and genotype distribution of cervical human papillomavirus DNA in women with normal cytology: a metaanalysis. Lancet Infect Dis 2007, 7:453-459.

23. An HJ, Cho NH, Lee SY, Kim IH, Lee C, Kim SJ, Mun MS, Kim SH, Jeong JK: Correlation of cervical carcinoma and precancerous lesions with human papillomavirus (HPV) genotypes detected with the HPV DNA chip microarray method. Cancer 2003, 97:1672-1680.

24. Lin H, Ma YY, Moh JS, Ou YC, Shen SY, ChangChien CC: High prevalence of genital human papillomavirus type 52 and 58 infection in women 
attending gynecologic practitioners in South Taiwan. Gynecol Oncol 2006, 101:40-45.

25. Hildesheim A, Wang SS: Host and viral genetics and risk of cervical cancer: a review. Virus Res 2002, 89:229-240.

26. Lin $M$, Yang $L Y, L i L J, W u$ JR, Peng YP, Luo ZY: Genital human papillomavirus screening by gene chip in Chinese women of Guangdong province. Aust N Z J Obstet Gynaecol 2008, 48:189-194.

27. Sukvirach S, Smith JS, Tunsakul S, Munoz N, Kesararat V, Opasatian O, Chichareon S, Kaenploy V, Ashley R, Meijer CJ, Snijders PJ, Coursaget P, Franceschi S, Herrero R: Population-based human papillomavirus prevalence in Lampang and Songkla, Thailand. J Infect Dis 2003, 187:1246-1256.

28. Smith JS, Lindsay L, Hoots B, Keys J, Franceschi S, Winer R, Clifford GM: Human papillomavirus type distribution in invasive cervical cancer and high-grade cervical lesions: a meta-analysis update. Int J Cancer 2007, 121:621-632.

29. Bao YP, Li N, Smith JS, Qiao YL: Human papillomavirus type distribution in women from Asia: a meta-analysis. Int J Gynecol Cancer 2008, 18:71-79.

30. Winer RL, Feng Q, Hughes JP, O'Reilly S, Kiviat NB, Koutsky LA: Risk of female human papillomavirus acquisition associated with first male sex partner. J Infect Dis 2008, 197:279-282.

31. Althoff KN, Paul P, Burke AE, Viscidi R, Sangaramoorthy M, Gravitt PE: Correlates of cervicovaginal human papillomavirus detection in perimenopausal women. J Womens Health (Larchmt) 2009, 18:1341-1346.

32. Brown DR, Shew ML, Qadadri B, Neptune N, Vargas M, Tu W, Juliar BE, Breen TE, Fortenberry JD: A longitudinal study of genital human papillomavirus infection in a cohort of closely followed adolescent women. J Infect Dis 2005, 191:182-192.

33. Goodman MT, Shvetsov YB, McDuffie K, Wilkens LR, Zhu X, Thompson PJ, Ning L, Killeen J, Kamemoto L, Hernandez BY: Prevalence, acquisition, and clearance of cervical human papillomavirus infection among women with normal cytology: Hawaii Human Papillomavirus Cohort Study. Cancer Res 2008, 68:8813-8824.

34. Castle PE, Schiffman M, Herrero R, Hildesheim A, Rodriguez AC, Bratti MC, Sherman ME, Wacholder S, Tarone R, Burk RD: A prospective study of age trends in cervical human papillomavirus acquisition and persistence in Guanacaste, Costa Rica. J Infect Dis 2005, 191:1808-1816.

35. Castle PE, Jeronimo J, Schiffman M, Herrero R, Rodriguez AC, Bratti MC, Hildesheim A, Wacholder S, Long LR, Neve L, Pfeiffer R, Burk RD: Agerelated changes of the cervix influence human papillomavirus type distribution. Cancer Res 2006, 66:1218-1224.

36. Bosch FX, Castellsague X, Munoz N, de Sanjose S, Ghaffari AM, Gonzalez LC, Gili M, Izarzugaza I, Viladiu P, Navarro C, Vergara A, Ascunce N, Guerrero E, Shah KV: Male sexual behavior and human papillomavirus DNA: key risk factors for cervical cancer in Spain. J Natl Cancer Inst 1996, 88:1060-1067.

37. Munoz N, Castellsague X, Bosch FX, Tafur L, de Sanjose S, Aristizabal N, Ghaffari AM, Shah KV: Difficulty in elucidating the male role in cervical cancer in Colombia, a high-risk area for the disease. J Natl Cancer Inst 1996, 88:1068-1075.

38. Kjaer SK, Chackerian B, Brule van den AJ, Svare El, Paull G, Walbomers JM, Schiller JT, Bock JE, Sherman ME, Lowy DR, Meijer CL: High-risk human papillomavirus is sexually transmitted: evidence from a follow-up study of virgins starting sexual activity (intercourse). Cancer Epidemiol Biomarkers Prev 2001, 10:101-106.

39. Bosch FX, de Sanjose S: The epidemiology of human papillomavirus infection and cervical cancer. Dis Markers 2007, 23:213-227.

doi:10.1186/1743-422X-7-66

Cite this article as: Ye et al:: Prevalence and risk profile of cervical human papillomavirus infection in Zhejiang Province, southeast China: a population-based study. Virology Journal 2010 7:66.

\section{Submit your next manuscript to BioMed Central and take full advantage of:}

- Convenient online submission

- Thorough peer review

- No space constraints or color figure charges

- Immediate publication on acceptance

- Inclusion in PubMed, CAS, Scopus and Google Scholar

- Research which is freely available for redistribution

Submit your manuscript at www.biomedcentral.com/submit
Biomed Central 